\title{
Interest Groups and Agent Network Analysis: Tools for Political Viabilization of Infrastructure Investment Projects
}

\author{
Joaquim José Guilherme de Aragão, Yaeko Yamashita, Anísio Brasileiro de Freitas Dourado, \\ Artur Carlos de Morais
}

\begin{abstract}
The present contribution addresses the construction of political wills in the elaboration of governmental projects. "Lack of political will" is often deplored when certain projects, even though they have their established value, can not be imposed on the government agenda or, when they do, are not effectively implemented. The literature has dealt with the issue from various angles and frames of reference (public policy cycles, stakeholder analysis, advocacy, among others). In order to test the explanatory power of the groups approach or the coalitions of interest (here treated as a synonym), in infrastructure policy, the present article explores the history and content of the concept and establishes a research roadmap to be applied in studies of the decision process in selected infrastructure projects.
\end{abstract}

Index Terms - Interest Group, political entrepreneur, infrastructure investment.

\section{INTRODUCTION}

The "lack of political will" is always alleged, in a mix of resignation and revolt, when public projects and actions of great utility or even social necessity are not able to get on the government agenda. In fact, a large number of value-aggregating ideas, even though some will already have consumed public resources in preparatory studies, provide every year, countless tombstones in a big dreams graveyard that is the public sector. Of this fate suffer even projects that for years, if not decades, have been enrolled in sectorial national plans.

However, behind this frustration, hides a poor comprehension of the public decision process behavior. It is extremely complex, given being "a continuum of decision-making moments" [1].

As the author warns, everything starts in the proposal insertion from a relevant problem, which is subject to state intervention and in the choice of solution alternatives. The author proceeds: "The transport sector is a fertile field in the actor request dispute and claims. Technical and political

Joaquim Jose Guilherme Aragão (Dr.) Professor of Faculty of Civil Engineering University of Brasília, Brazil,

Yaeko Yamashita (PhD) Professor of Faculty of Civil Engineering University of Brasília, Brazil

Anísio Brasileiro de Freitas Dourado (Dr.) Rector of Federal University of Pernambuco. Brazil

Artur Carlos de Morais (Dr.) Professor of Faculty of Civil Engineering University Center Estácio of Brasília, Brazil clashes are caused by a large number of existing demands and also, mainly, for the amount of resources involved."

What makes the battle for project injections in the public agenda even harder is the clash, inner and outer to the public sector interest disputes, during a long range of different stages, which are, problem identification and prioritization (agenda formation); search for alternatives; execution and preparation of the implementation; and the later evaluation [2], [3], [4], [5], [6], [7], [8], [9], [10]. In each stage, the proposing individual of a specific project will encounter different agents, both supporters and opponents.

The government reaction to the propositions depends, equally, in its way of selecting options and the space it admits to the participation in the decision-making process [11], [2], [13]. Is it a government that adopts a structured planning with a specific priority agenda; or a government that keeps grasping, one by one, loose ideas to solve different problems? Or, still, a government that prefers or, instead, eludes projects with wider reach and structuring effect; in the latter, prioritizing solutions that are merely incremental to the pre-existing action framework? At last, in which level of rationality, effective correspondence to the social needs, and efficiency does the public decision operate?

As for the amount of space that is open for participation, the State can be closed, like and elite that decides for the sake of society, allowing very limited opportunities for cooperation among sectors outside the public machine (Elitist State); can be, instead, open and even dependent of outside propositions, almost imposed by external groups with different degrees of power (Pluralist State); or, still, a State where decisions are made according to interests of public and private entities (Corporative State; see: [13],[14].

Therefore, the defense of projects of big public utility, thus the construction of the so-called "public wil" requires the analysis of all these processes, but a true political engineering as well. This is the central objective of this current article. Being a project on a sector in which there was not enough attention, water transportation, it is necessary to know the political means in order to increase the odds of it effectively entering the government agenda.

From the principle of the mild weakness in government planning, even when it exists on paper, the decision-making 
process in our country has been mostly following the "Pluralist State" model, it must be concluded that smart mapping of actors and the formation of interest groups or coalitions are a central problem of transportation sectoral research. This contribution has its focus on that problem.

This article has a literature review character about interest groups and actor analysis. In this review, the objective is to build a case analysis tool. By hypothesis, the case study of the successful or unsuccessful experiences in implementing waterways will provide indications of building more effective political tactics and strategies. In following studies, which will come from case analysis, it will be possible to build, step by step, efficient procedures of building coalitions to stand for waterway projects.

Such review requires a preliminary analysis about how the interest groups and coalitions were formed during the decades, where it was detected that the decision-making process of the government do not correspond to the juridical and idealistic vision of the State: Different opposite forces act in an extremely complex manner. Literature about Interest Groups and coalitions scrutinizes the organization and procedures of the groups and how they enforce the "pluralist" character of the State. However, this pluralism is not democratic, as the groups represent interests that possess expensive resources to organize and maintain them.

This way, the interests that can structure themselves and act in the best way are victorious. Regardless the value given to this state of things, the organizational and active techniques need to be acknowledged and, better than that, appropriated by those who fight for causes of large public interest: democratic idealization can be rewarding to scholars that are distant of concrete struggles in society.

Considering that, the present article is structured in the following way: in Section 2, a literary review about interest groups is presented, containing the origin and history the concept and its discussion; about the creation, structuration and actions of the groups; also about its effects on public policies and the transformations caused by these groups between the State and civil society. Section 3 discussed the spread of interest groups in the world.

The article, however, has a practical sense of politically equipping the infrastructure projects implantation. This way, besides analyzing literature, there is a concern of taking practical lessons to create interest groups that defend infrastructural investments. Section 4 produces a practical summary of the literature on the form of lessons on building interest groups. Nevertheless, it is considered that these lessons will not produce results without on-site observations of concrete experiences. So, Section 5 starts from the lessons structure elaborated in Section 4 to propose a case study evaluation instrument, in the shape of a questionnaire to be applied in the study. Section 6 closes the article with its conclusions.

\section{INTEREST GROUPS AND COALITIONS}

\section{A. History of a Discussion}

Interest Group is defined as a group that produces, represents and tries to impose or defend an interest or a cause of a specific section of society in the public space, influencing political powers [13], [14]. The emergence of these groups in the political scene and their increasing power to interfere in the decisions of the Public Powers, challenging hierarchies of the constituted power, has been attracting the attention of researchers of State actions and public policies, more strongly since the nineties past.

However, as [13] cautions, this phenomenon is not new. Since the late nineteenth century the phenomenon of lobbying, strong in the United States, has been well known, and several authors have since dedicated studies to this phenomenon (Bentley, Beard, Dewey, Veblen; apud [13]). The criticism of these practices caused its regulation, which has, on the other hand, facilitated its expansion, once legalized. On the research field, then, the interest group topic was created.

One of the effects of this practice is the construction of a State open to influences from sectors of society, challenging centralized procedures. However, such a "Pluralist" State does not necessarily imply a democratization of the process, and it has been the object of numerous critical studies ([13]. If in the beginning the phenomenon was confined to the American reality, whereas in Europe the power of bureaucracy and corporations was little permeable to influences of organized groups, the countries of the latter have increasingly adhered to the pluralistic model, since the end of the Second World War. In research, the term pressure groups have been giving space to the interest group one, investigating its relationship with current political organizations (parties, unions, associations) and their effects on the governmental decision-making process and on the character of the State itself. With the development of regional cooperation, European lobbying has gained increasing ground in the European Union.

Internationally, the building of interest groups, also called coalitions [15], [16], [17], has not only been accepted, but also recommended as instruments for the still disarranged and fragile forces of society to be heard and to impose their interests.

\section{B. The Genesis of Interest Groups}

As [13] summarizes, three elements are constituents of the genesis of Interest Groups (or coalitions): the formation of interest, the organization of the group and its legal institution. As far as group interests are concerned, they do not exist in themselves, but rather come to the surface by actions of agents who possess political, financial and social resources [14]. The emergence of groups that defend them should be attributed to the insufficiency of the initiatives of the current political institutions (state, parties) to serve them [13]. Such insufficiency may be structural, given the increasing complexity of society and its demands; or conjunctural, derived from a change that requires a new accommodation of interests.

What would these interests be? In fact, they can be of different natures. [17] and [18] propose the following classification: first, interests can be collective or selective. In the latter case, they concern a limited group. Secondly, interests can be immediately material (assets and financial 
resources), directly affecting the members of the group; or from solidarity, arising from a process of social interaction, which lead people to participate in the decision-making process on matters relating to different groups of people and to manifest themselves; or ideological, that is, arising from a need for moral satisfaction and civic conviction. The latter are necessarily collective interests.

But what motivates individuals to actively participate in the interest group and their actions? This adherence is based on the following assumptions (The World Bank): there must first be an identification of the potential adherents with the collective represented by the group. Secondly, such adherence must correspond to a value (solidarity, civic spirit) or a concrete need. Finally, the interest group opens a concrete perspective of realizing the interest, given the organizational, political and financial resources that it has. These motives are considered with political assets [13].

The accession process and the characteristics of the adherents depend on the nature of the interest concerned, i.e. the political good at stake. However, such membership can be effective, where members participate in activities to defend the interests and organization of the IG; or passive, where the formally adherent only expects the result of the IG's actions. Among those who are passively adherent, there are those who at least provide resources, financial or otherwise, and free-riders. They expect the result of the struggles, which is in their interest, without the least effort and risk, which discourages membership or active participation in fighting activities.

Also, membership may be temporary. According to [17], the strength of the group lasts until interests are effectively met, causing the group to extinguish or weaken after the victory.

Another aspect to consider is that the immediate object of the struggle, if finally won, is not the only benefit. New circles of friendship, but also gaining notoriety, may be included in the participant's list of dividends [13]. Building bonds of identity, friendship, and mutual trust is a key ingredient for the dynamics of Interest Groups, which can help their survival to victory (or defeat), or the formation of another group, for a new cause.

It should not be forgotten that the State itself can be an articulator of interest groups, insofar as it resolves to share responsibility for decisions with agents of society.

\section{The Organization and the Actions of Interest Groups- GI}

To be successful in the imposition of its requests, it is indispensable that the Group of Interest has organizational resources, that is, financial resources; an organized, hierarchical structure; quality professional staff; and capable leadership [14].

In fact, there is an art in starting, building and leading interest groups and coalitions. Such art is not generalized among adherents, but rather focused on capable leaders, who the literature designates as political entrepreneurs, and who devote almost full-time to this task [14]. These stand out from the mass of stakeholders and potential adherents, leading the formation of the group and its action. In addition to the leadership capacity, which can effectively influence the group and the political process, they need access to strategic contacts (political resources), funding and technical knowledge [13].

Often, this political entrepreneur comes from branches of Administration or Politics; eventually, they are marginalized and need action that values them politically to regain their influence (this history is not necessarily the only one). Yet, they may arise from dissimulations of pre-existing organizations or from personal traumas. The provenance of leaders and their motives will of course influence their style of command and the organization and history of the group itself.

Centralizing the organization and conducting the interest group by the entrepreneur can streamline the process, but also produce a series of risks. The ability to speak, act, mobilize interests, represent a relevant segment of the public can be used for purposes other than the interests at stake, leading to decisions and actions that deviate from the objectives of the struggle.

In any case, the procedures chosen by the entrepreneur and the techniques employed in the struggle must be distinguished by their creativity and even innovation, in order to surprise decision-makers, opponents and public opinion in general. Modern techniques such as mapping and monitoring of agents and facts ie strategic, tactical, and operational intelligences need to be mastered.

In this context, the literature [18], [19] refers to repertoires of action. Actions can be internal, or external. In the first case, it is assumed that the Interest Group and its entrepreneur already have reasonable access to the decision maker and are able to influence them through a series of services and activities within the administrative machine such as studies, participation in hearings, provision of information, etc.. This access can originate from the capital of relations that the entrepreneur already has; or have been acquired throughout the fight. In the case of external actions, the group would, in principle, be excused from access to the access taker, so it has to prioritize other institutions (legislative, judiciary), organizations and associations already influential; or public opinion (press, social movements). Table 1 provides a systematization of action spaces already listed in the literature.

Internal actions, also called internal lobbying, are those that most immediately lead to the imposition of interests. They already reflect a degree of intimacy with decision-makers. However, they can create a dependence on decision makers, as they result from compromises that tie the interest group and its leadership and may lead to renounces and deviations from the initial goals of the movement.

In turn, external actions (external lobbying) rescue the political freedom of the group, but they mean that it has not yet been sufficiently successful in imposing interests. In this way, fighting in the external arenas of power is the strategy of excluded or for not yet included in it.

The construction of an Interest Group or a coalition runs through several phases[20]:

a) The identification of a cause or interest worth fighting for, insofar as it affects the interest of a relevant set of people; and has a potential for mobilization;

b) The construction of a strategic intelligence, which maps the relevant agents involved in the cause or interest including potential or actual adversaries;

c) Identification and mobilization of stakeholders and the construction of the movement and its organization; 
d) Creation of credibility and representativeness of the group or coalition, through the implementation of the repertoire of actions;

e) Growth of the movement and its political force, to victory in terms of influence over public policy;

f) Management of the decision-making process and implementation of measures that correspond to the interests defended.

A critical success factor for the actions promoted by the interest group is communication. The instruments of communication vary according to the types of action selected from the repertoire, as well as from each stage of the struggle construction. Inquiries to interested parties; specialists and people close to the decision-maker are important in the identification of interest and the assembly of strategic intelligence, as well as in the mobilization of stakeholders. This consultation requires that the leadership of the movement knows how to listen attentively to stakeholders, adversaries and decision makers. In the next phases of building credibility, growth of the movement and the management of implementation, channels of communication with a wider public should be added.

\section{The Transforming Effects of Interest Groups and Coalitions on the State}

In a reading of the state as a set of administrative and political actors that meet demands of society [14], interest groups play a role of mediating society and the State, translating aspirations and demands, but also filtering selected solutions [13].

However, even when interest groups are increasingly important, the relationship between them depends on the structuring and conducting characteristics of the state; the level of centralization and federalization; and, within the State, of each administrative sector. The styles of government also interfere in relations: dirigiste states, where an organized and competent bureaucracy dominates strongly the decision process; and also, in those states where statute corporations have a great veto power in demands from society, groups may have less space than states that dialogue more strongly with (pluralist) society. In the former, interest groups have to focus their actions on protest, on partisanization of causes, and on the use of courts [14]. However, such actions can further deepen the gap between the groups and the state, making their effects even more unpredictable.

In pluralist states, a style that has spread in the neoliberal era, the relationship between groups and state agents maintains several ties of cooperation and may lead to clientelistic ties (dependence on groups of politicians) or interference of more organized groups in public policy ("Neo-corporatism"). Especially the more structured groups have the capacity to offer studies and projects to the State, as well as strategic information, sometimes forming real think tanks. However, the intensity of cooperation and the strong investment in information provision do not guarantee a satisfactory response to the demands: the provision of expertise does not always translate into recognition of the legitimacy and representativeness of the interest group. In addition, the group has to fight competing interests, which can also be run by highly organized groups.

In practice, internal and external actions are not mutually exclusive: even in groups with broad access to the offices of decision-makers, they may choose to complement and reinforce the weight of internal actions with external ones (parliamentary and judicial pressure). Here too, cooperation ties can be established in the form of bills and support for court decisions such as opinions, testimony, initiation of actions, etc..

\section{THE SPREAD OF PRACTICES OF INTEREST GROUPS AND LOBBYING IN THE WORLD}

Although the classification of governance styles as a theoretical construct is subject to much criticism, the fact is that, unlike the United States, the strength of lobbying and interest groups was late, partly because of the globalization process of economy [14]. This created interdependence between national economies and the strengthening of large transnational capital groups.

In the most recent transformations, the State "public service provider" has given space to the "regulator", and it is up to it to hire and control services offered by the private sector. On the other hand, the private sector has gained space for articulation with the state as a contractor and not just as a political claimant, opening spaces for regulatory capture. But equally, challenging groups have recognized the potential of imposing themselves on the public manager through external lobbying practices, and then internally for example, by hiring non governmental organizations.

At the international level, the pluralist style started with the United States, the "home of lobbying". The United Kingdom, long dominated by the welfare state, gave way to pluralism, mainly due to the strengthening of environmental organizations.

Other countries, still dominated by the corporate styles implanted as a result of agreements between the State, employers 'and workers' unions to guarantee "social peace" and "social partnership" (Sweden, Germany and Austria), are increasingly eroding this class cooperation in view of the need to adapt labor legislation to the facts created by international competition; as a result, labor reforms that favor sectoral or enterprise agreements have begun to erode the power of trade unions and therefore also their power to influence public policies. However, channels of participation in planning such as public hearings, discussion in the network, open spaces for social organizations to pronounce on government projects; however, such a move, far from restoring power to corporations, accelerates the transformations towards the pluralist style of governance. Styles and changes vary by sector. The European agricultural sector, long protected from international competition, has for a long time imposed a corporate style on the condition of sectoral policy. The recent opening of the agricultural market weakened the power of peasant associations and federations. Corporate style has also long dominated the various subsectors of infrastructure (electricity, transport, water and sanitation, etc.). Environmental policy was born in the pluralist culture, in that the respective interest groups had to use a well-structured and decisive external lobbying to impose itself. Something similar can be said with regard to the defense of consumer rights.

Today, in the era of globalization and the establishment of regional agreements, international and regional lobbying is part of the conduct of international policies. Campaigns and International Non-Governmental Organizations (Greenpeace, Amnesty International, Doctors Without Borders, etc.) are highly influential agents in multilateral organizations. In turn, the opening up of trade and services is imploding more and more nationally based corporations (eg 
in air transport). In turn, trade unions are forced to establish cooperation ties between national entities, to rescue their influence power.

At the national level, the imposition of the pluralistic style is aided by multilateral entities (World Bank, Inter-American, etc.), which provide resources and courses for the organization of interest groups, especially of strata and social sectors with relatively low power of influence (family farming, public health, rural education, etc.).

Some illustrative examples of this pluralistic transformation of public policy are described below.

a) coalition for transparency and accountability in the Philippines

In the late 1990s, the Asia Foundation was able to build a coalition to fight corruption and promote an improved environment for economic growth. Initially partnering with academic institutions to conduct research to address the problem of corruption in the Philippines, the creation of the TAG website (http://www.tag.org.ph) proved to be a powerful tool for empowering citizens and motivating them to participate by making their contribution visible in an area accessible to the public.

b) coalition of water sector reform in Kenya

In the late 1990s, chronic water shortages created an aspiration among citizens for sectoral reforms. The Ministry of Water and Irrigation therefore had the initiative to build a coalition not only between people and groups who were dissatisfied with the water services administration so far but also with other bodies that needed to be associated with these reforms, especially the management of the new government, which had campaigned on a platform prioritizing good governance and improving the provision of public services. The success of the reform was due to a consensus and a mobilization of stakeholders. A steering committee composed of key stakeholders and an independent implementation unit were formed.

Many powerful and established long-standing groups opposed change, each with its own argument to maintain the existing power structure. In support of reform, the government used the coalition to neutralize opponents, which required the deployment of sophisticated communication techniques. In addition, a broad and transparent dialogue was developed between managers, unions and government, with a view to identifying common problems, analyzing problems faced by most public enterprises, and exploring new institutional options.

\section{COALITION BUILDING FOR INFRASTRUCTURE PROJECTS: LESSONS FROM LITERATURE}

What lessons do the literary review of interest groups allow for coalitions to advocate for particular infrastructure projects? At the outset, the interest must be raised, from problems expressed either by the government or by the private sector, problems that demand a solution.

Project initiators should design a solution proposal that addresses the needs of potential applicants, as well as look for potential leaderships for an organized movement. This is an extremely difficult and critical moment of the initiation of the movement, as idealizers, who are often problem-solvers and solution-builders, and participate in engaged research efforts, rarely possess the gifts of a leader.

The search for them goes through several attempts, risks and disappointments, until the right person is reached. He or she may come from a variety of backgrounds such as businessmen, government cadres, or politicians in distress or with prospects who are interested in ideas that not only bring benefits to society but also promise them personal fulfillment.

It will be up to these leaders, who need to be able to capture and manage resources; intellectual capacity; as well as the capacity for relationship, to turn the solution into a "political asset," which may be a legal investment, business opportunity and legal reform that creates prospects for progress and problem solving.

From this structuring stage, the next step would be to build an organization and seek adherence. At this point, a study of actors and social networks can serve as a valuable tool. In addition to social analysis tools, the organization has to carry out a strategic planning, building a repertoire of varied actions, to be applied in several instants and phases of the movement. Various technical resources (mapping, monitoring), a more in-depth study of problems, of solutions belonging to the governmental agenda, but also of influential groups and, finally, the effective application of lobbying tools come into use; as described in Table 1.

Another measure is the internal organization of the interest group. In addition to the legal institution, adequate human resources must be contracted to carry out the various tasks included in the repertoire of actions; as well as the search and administration of the necessary financial resources.

Obviously, it is not a question of drawing a "recipe": the movement, its actions and structuring should always take into account the autonomy of decision makers and the limits to influence them; as well as competition between competing interest groups and the advocacy that dominant groups hold against movements and actions that threaten their interests. The dynamics of this social interaction are replete with unpredictable upheavals, which will require a reanalysis and permanent readaptation of the selected strategies and tactics.

\section{THE RESEARCH OF EXPERIENCES AS A HEURISTIC TOOL AND A SCRIPT PROPOSAL}

Although history can not always serve as a master for action in the present, given the extreme range of circumstances in which decisions, movements and clashes have taken place, the experience of cases usually produces some useful indicatives that mere literary revision does not is able to provide. Especially the comparison with situations, problems and similar projects may be fruitful.

What, however, do we want with the analysis of similar experiences to a particular movement and the structuring of interest groups? The following goals can be listed:

- To know, in a general way, the great moments of the formation and performance of the coalition / IG in the congener case;

- To understand the emergence of interests that lead to the formation of coalitions and IGs and their political and economic constraints;

- To understand the concrete benefits of building the coalition / IG: that is, the material, moral, and political benefits that each participant group expected when it joined the movement;

- To know the process of genesis of the initiative and the political entrepreneurs involved, including their origin and motivation; 
- To know the process of enrollment of members and their profiles;

- To point out the role and requirements of technical training, social training and accessibility of resources presented by the leaders;

- To know the technical resources that have become indispensable to the coalition / GI

- To know the acquisition and application of financial resources;

- To know the repertoires of action (internal / external lobbying) used by the coalition / IG and their respective successes and failures;

- To know and measure political success in terms of:

- Political recognition;

- Recognition of the representativeness of members and the maintenance of their cohesion;

- Success / failure to meet the interests and respective requests;

- To know the effects of the action of the interest group on public policies, legislation and jurisprudence;

- To know the development of the relationship with the politicians and the Public Administration, their mishaps and successes / failures;

- To know the conditions to which the movement submitted itself in the relationship with the Public Power;

- To know the conflicts between the adherents and the coalition / IG and, in particular between the adherents and their leadership;

- To know the conflicts between the GI / coalition and other economic actors that had their interests affected; Lastly,

- To know the process of succession of leaders. Based on such knowledge needs, can be applied with open questionnaire to selected people.

\section{CONCLUSIONS AND PERSPECTIVES}

Public investment projects and public policies, even if already prepared, usually run into the decision-making process, leading their public and private protagonists to discouragement and the realization that "there was a lack of political will." However, the construction of this political will is not something that follows once the policy, investment or legal reform project is prepared. It is necessary that the protagonists begin to deepen in political matters.

In this deepening of the political conditions of the decision, the phenomenon of interest groups assumes a greater role not only in the research of public policies, but also in the struggle for the realization of projects. In fact, as reviewed in this article, the formation, organization and actions of interest groups or coalitions play an increasing role in asserting projects with decision makers, and the State is forced to open its decision-making process to non-state organizations of society.

Critical moments on this path of struggle to victory are the emergence of interests that have not been contemplated by the conventional ways of public management and which need to be imposed through the organization of groups / coalitions of interest. Such interests need to be recognized by a community so that it mobilizes for its service. The organization; the process of obtaining adhesions; just as strategies and tactics of action (repertoire of actions) need to be decided and operated.

However, this structuring does not occur spontaneously, within the community of those affected by the interest in question. In fact, the process needs to be awakened and led by a person or group of people, who have the communicative and organizational capacity, contacts and indispensable resources so that the group can structure itself and exercise, through its actions, a strong influence over those who make the decisions.

This generic list of elements will, of course, vary from the character of the object of interest, demanding the discovery, on a case-by-case basis, of the paths of struggle and success. Organizational structures, the origin of adherents; the leadership profile, the financial and material resources to the repertoire of action are specific to each case.

It is necessary, therefore, to analyze experiences that are specific to each type of demand so that there is a greater understanding of the barriers and paths that have led similar experiences to victory or defeat. In the present article, based on the literature review, a research method for the understanding of the experiences was sketched, which requires clarifying, for each case study, the concrete objectives of the research; the history of the case study; the genesis of demands that are transformed into interests that motivate the formation of groups; organization and leadership; the repertoires of action, the resources made available, as well as the results of the struggle of the group or coalition of interest.

Understanding the context and process of struggle in each type of demand and interest, and the consequent building of interest groups and their actions, are no magic recipe for success. The group will have to fight hard for its interest, fighting against conflicting interests and the public machine itself, which does not always willingly accept pressure from organized groups in society. Therefore, the result will always be uncertain. However, organizing interest groups and executing a well-planned mobilization strategy, built on theoretical knowledge and from the analysis of similar cases, can at least increase the likelihood of success.

In short, this is a relevant issue that needs to be included in the research agenda on infrastructure policies and projects (transportation, water resources and sanitation, electricity and telecommunications), as well as agroindustry and tourism complexes and new cities. Such deepening can reduce the rate of frustration for those who work in these sectors

\section{REFERENCES}

[1] Morais, A. C.; Aragao, J. J. G.; Yamashita, Y.; Orrico, R. D.; Dourado, A. B. Analysing the fiscal sustainability of transit investment projects: the case of the metropolitan railway of brasília. In: 13th International Conference on Competition and Ownership in Land Passenger Transport, 2013, Oxford. Proceedings of the 13th International Conference Series on Competition and Ownership in Land Passenger Transport. Oxford, Reino Unido: University of Oxford, 2013. v. 1. p. 1-14

[2] Souza, C.; Políticas Públicas: Revisão da Literatura. Sociologia. Porto Alegre, ano 8, $\mathrm{n}^{\circ}$ 16, 2006,p. 20-45

[3] Kingdon, J.; Agendas, Alternatives, and Public Policies. $2^{\mathrm{a}}$ edition. 1995, New York, Longman 
[4] Subaris, J.; Definición del Problema. Relevancia Pública y Formación de la Agenda de Actuación de los Poderes Públicos. In: Saravia, E e Ferrarezi, E. Políticas Públicas; Coletânea. Brasília: ENAP; 2006, volume 1

[5] Rua, M. G., Análise de Políticas Públicas: Conceitos Básicos, Web Document (accessed in Sept. 12th 2017): http://estadoedemocracia.blogspot.com/2007/08/analise-de-politicaspublicas-conceitos.html. Accessedin: Oct. 16th 2007

[6] Travis, R. e Zahariadis, N.; A Multiple Streams Model of U.S Foreign Aid Policy. Policy Studies Journal, 30, 4, 2002, 495-514.

[7] Gomide, A. A.; Agenda Governamental e Formulação de Políticas Públicas: o projeto de lei de diretrizes da política nacional de mobilidade urbana. Texto para discussão 1334. Brasília, 2008, IPEA

[8] Gelinski, C. R. O. G.; Seibel, E. J.; Formulação de políticas públicas: questões metodológicas relevantes. Available at http://www.cfh.ufsc.br/ revista/rch42/RCH42_artigo_10.pdf. Accessed in April 12th, 2011

[9] Sato, H.; Frantz, J. E.,Termination of the leprosy isolation policy in the US and Japan : Science, policy changes, and the garbage can model. BMC International Health and Human Rights, 2005, 5:3

[10] Lindblom, C. E. O; Processo de Decisão Política. Brasília, 1982, Ed. UnB

[11] Santos, L. A.; Regulamentação da Atividade de Lobby e seu Impacto sobre as Relações entre Políticos, Burocratas e Grupos de Interesse no Ciclo de Políticas Públicas: Análise Comparativa dos Estados Unidos e Brasil. Doctoral Thesis, 2007, UnB

[12] Dye, T. R.; Mapeamento dos Modelos de Análise de Política Públicas In: Heidemann, F. G. e Salm, J. F. (orgs). Políticas Públicas e Desenvolvimento: Bases Epistemológicas e Modelos de Análise. Brasília,2009, Editora UnB.

[13] Courty, G.; Les groups d'intérêt. Collection Prepères. Paris : 2006, La Decouverte

[14] Grossman, E; Saurugger,; Les groups d'intérêt. Action collective et stratégies de représentation. Paris: Armand Colin, 2006.

[15] Danish Institute for Parties and Democracy; Coalition Building. Finding solutions together. 2015, Web Document (accessedinSept. 2nd 2017): http://forskning.ruc.dk/site/files/58231613/DIPD COALITION BU ILDING READER.pdf

[16] Community Catalyst: Strength in Numbers: A Guide to Building Community Coalitions. 2003, Web Document (accessed inSept. 2nd 2017):

https://www.communitycatalyst.org/doc-store/publications/strength in_numbers_a_guide_to_building_community_coalitions_aug03.pdf

[17] Olson, M.; La logique de la action collective. Paris : 1987, PUF.

[18] Sabatier, P.A.; Interest group membership and organization: multiple theories. In Petracca,M.P. (ed.): The politics of interest Boulder, 1992. Westview Press

[19] Della Porta, D., Diani, M.; Social movements: an introduction. 2nd ed. London: Blackwell, 2006.

[20] Tilly, C.; From Mobilization to Revolution. University of Michigan. CRSO Working Paper 156. 1977, Web Document (accessed inSept. 2nd 2017): https://deepblue.lib.umich.edu/bitstream/handle/2027.42/50931/156. pdf

[21] The World Bank; Coalition building. Communication for Governance and Accountability Program (CommGAP). Washington, DC: World Bank. 2010, Document Web (accessed em 2/09/2017) http://documents.worldbank.org/curated/en/301231468332369676/C oalition-buildin 